\title{
Growth of Life Insurance Business in India: A Study
}

\author{
Pranam Dhar \\ Department of Commerce \& Management, West Bengal State University, West Bengal, India
}

Corresponding author : pranamdharit@yahoo.com

\begin{abstract}
In India, insurance has a deep-rooted history. It finds mention in the writings of Manu (Manusmrithi), Yagnavalkya (Dharmasastra) and Kautilya (Arthasastra). The writings talk in terms of pooling of resources that could be re-distributed in times of calamities such as fire, floods, epidemics and famine. This was probably a pre-cursor to modern day insurance. Ancient Indian history has preserved the earliest traces of insurance in the form of marine trade loans and carriers' contracts. Insurance in India has evolved over time heavily drawing from other countries, England in particular. Life Insurance in its modern form came to India from England in the year 1818. Oriental Life Insurance Company started by Europeans in Calcutta was the first life insurance company on Indian Soil. All the insurance companies established during that period were brought up with the purpose of looking after the needs of European community and Indian natives were not being insured by these companies. The insurance sector has gone through a number of phases by allowing private companies to solicit insurance and also allowing foreign direct investment. India allowed private companies in insurance sector in 2000 , setting a limit on FDI to $26 \%$, which was increased to $49 \%$ in 2014. However, the largest life-insurance company in India, Life Insurance Corporation of India is still owned by the government and carries a sovereign guarantee for all insurance policies issued by it. The present study examines the growth Life Insurance business in India. Popular financial tool like CAGR is used for the study along with some popular statistical tools like t-test and ANOVA. Secondary data published by IRDA and the Annual Reports of LICI is used for the study for a period from 2008-09 to 2016-17. The study is empirical in nature.
\end{abstract}

Keywords : LICI, CAGR, IRDA, Anova

\section{INSURANCE IN INDIA}

In India, insurance has a deep-rooted history. It finds mention in the writings of Manu (Manusmrithi), Yagnavalkya (Dharmasastra) and Kautilya (Arthasastra). The writings talk in terms of pooling of resources that could be re-distributed in times of calamities such as fire, floods, epidemics and famine. This was 
probably a pre-cursor to modern day insurance. Ancient Indian history has preserved the earliest traces of insurance in the form of marine trade loans and carriers' contracts. Insurance in India has evolved over time heavily drawing from other countries, England in particular.

1818 saw the advent of life insurance business in India with the establishment of the Oriental Life Insurance Company in Calcutta. This Company however failed in 1834. In 1829, the Madras Equitable had begun transacting life insurance business in the Madras Presidency. 1870 saw the enactment of the British Insurance Act and in the last three decades of the nineteenth century, the Bombay Mutual (1871), Oriental (1874) and Empire of India (1897) were started in the Bombay Residency. This era, however, was dominated by foreign insurance offices which did good business in India, namely Albert Life Assurance, Royal Insurance, Liverpool and London Globe Insurance and the Indian offices were up for hard competition from the foreign companies.

In 1914, the Government of India started publishing returns of Insurance Companies in India. The Indian Life Assurance Companies Act, 1912 was the first statutory measure to regulate life business. In 1928, the Indian Insurance Companies Act was enacted to enable the Government to collect statistical information about both life and non-life business transacted in India by Indian and foreign insurers including provident insurance societies. In 1938, with a view to protecting the interest of the Insurance public, the earlier legislation was consolidated and amended by the Insurance Act, 1938 with comprehensive provisions for effective control over the activities of insurers.

The Insurance Amendment Act of 1950 abolished Principal Agencies. However, there were a large number of insurance companies and the level of competition was high. There were also allegations of unfair trade practices. The Government of India, therefore, decided to nationalize insurance business.

An Ordinance was issued on $19^{\text {th }}$ January, 1956 nationalising the Life Insurance sector and Life Insurance Corporation came into existence in the same year. The LIC absorbed 154 Indian, 16 non-Indian insurers as also 75 provident societies - 245 Indian and foreign insurers in all. The LIC had monopoly till the late 90 s when the Insurance sector was reopened to the private sector.

The history of general insurance dates back to the Industrial Revolution in the west and the consequent growth of sea-faring trade and commerce in the $17^{\text {th }}$ century. It came to India as a legacy of British occupation. General Insurance in India has its roots in the establishment of Triton Insurance Company Ltd., in the year 1850 in Calcutta by the British. In 1907, the Indian Mercantile Insurance Ltd, was set up. This was the first company to transact all classes of general insurance business.

In 1957, the formation of the General Insurance Council, a wing of the Insurance Association of India. The General Insurance Council framed a code of conduct for ensuring fair conduct and sound business practices. In 1968, the Insurance Act was amended to regulate investments and set minimum solvency margins. The Tariff Advisory Committee was also set up then. In 1972 with the passing of the General Insurance Business (Nationalisation) Act, general insurance business was nationalized with effect from $1^{\text {st }}$ January, 1973. 107 insurers were amalgamated and grouped into four companies, namely National Insurance Company Ltd., the New India Assurance Company Ltd., the Oriental Insurance Company Ltd and the United India Insurance Company Ltd. The General Insurance Corporation of India was incorporated as a company in 1971 and it commence business on January 1sst 1973.

This millennium has seen insurance come a full circle in a journey extending to nearly 200 years. The process of re-opening of the sector had begun in the early 1990s and the last decade and more has seen 
it been opened up substantially. In 1993, the Government set up a committee under the chairmanship of RN Malhotra, former Governor of RBI, to propose recommendations for reforms in the insurance sector. The objective was to complement the reforms initiated in the financial sector. The committee submitted its report in 1994 wherein, among other things, it recommended that the private sector be permitted to enter the insurance industry. They stated that foreign companies be allowed to enter by floating Indian companies, preferably a joint venture with Indian partners.

Following the recommendations of the Malhotra Committee report, in 1999, the Insurance Regulatory and Development Authority (IRDA) was constituted as an autonomous body to regulate and develop the insurance industry. The IRDA was incorporated as a statutory body in April, 2000. The key objectives of the IRDA include promotion of competition so as to enhance customer satisfaction through increased consumer choice and lower premiums, while ensuring the financial security of the insurance market.

The IRDA opened up the market in August 2000 with the invitation for application for registrations. Foreign companies were allowed ownership of up to $26 \%$. The Authority has the power to frame regulations under Section 114A of the Insurance Act, 1938 and has from 2000 onwards framed various regulations ranging from registration of companies for carrying on insurance business to protection of policyholders' interests.

In December, 2000, the subsidiaries of the General Insurance Corporation of India were restructured as independent companies and at the same time GIC was converted into a national re-insurer. Parliament passed a bill de-linking the four subsidiaries from GIC in July, 2002.

Today there are 28 general insurance companies including the ECGC and Agriculture Insurance Corporation of India and 24 life insurance companies operating in the country.

The insurance sector is a colossal one and is growing at a speedy rate of $15-20 \%$. Together with banking services, insurance services add about 7\% to the country's GDP. A well-developed and evolved insurance sector is a boon for economic development as it provides long- term funds for infrastructure development at the same time strengthening the risk taking ability of the country.

The story of insurance is probably as old as the story of mankind. The same instinct that prompts modern businessmen today to secure themselves against loss and disaster existed in primitive men also. They too sought to avert the evil consequences of fire and flood and loss of life and were willing to make some sort of sacrifice in order to achieve security. Though the concept of insurance is largely a development of the recent past, particularly after the industrial era - past few centuries - yet its beginnings date back almost 6000 years.

Life Insurance in its modern form came to India from England in the year 1818. Oriental Life Insurance Company started by Europeans in Calcutta was the first life insurance company on Indian Soil. All the insurance companies established during that period were brought up with the purpose of looking after the needs of European community and Indian natives were not being insured by these companies. However, later with the efforts of eminent people like Babu Muttylal Seal, the foreign life insurance companies started insuring Indian lives. But Indian lives were being treated as sub-standard lives and heavy extra premiums were being charged on them. Bombay Mutual Life Assurance Society heralded the birth of first Indian life insurance company in the year 1870, and covered Indian lives at normal rates. Starting as Indian enterprise with highly patriotic motives, insurance companies came into existence to carry the message of insurance and social security through insurance to various sectors of society. Bharat Insurance Company (1896) was also one of such companies inspired by nationalism. The Swadeshi movement of 
1905-1907 gave rise to more insurance companies. The United India in Madras, National Indian and National Insurance in Calcutta and the Co-operative Assurance at Lahore were established in 1906. In 1907, Hindustan Co-operative Insurance Company took its birth in one of the rooms of the Jorasanko, house of the great poet Rabindranath Tagore, in Calcutta. The Indian Mercantile, General Assurance and Swadeshi Life (later Bombay Life) were some of the companies established during the same period. Prior to 1912 India had no legislation to regulate insurance business. In the year 1912, the Life Insurance Companies Act, and the Provident Fund Act were passed. The Life Insurance Companies Act, 1912 made it necessary that the premium rate tables and periodical valuations of companies should be certified by an actuary. But the Act discriminated between foreign and Indian companies on many accounts, putting the Indian companies at a disadvantage. The first two decades of the twentieth century saw lot of growth in insurance business. From 44 companies with total business-in-force as ₹ 22.44 crore, it rose to 176 companies with total business-in-force as ₹ 298 crore in 1938. During the mushrooming of insurance companies many financially unsound concerns were also floated which failed miserably. The Insurance Act 1938 was the first legislation governing not only life insurance but also non-life insurance to provide strict state control over insurance business. The demand for nationalization of life insurance industry was made repeatedly in the past but it gathered momentum in 1944 when a bill to amend the Life Insurance Act 1938 was introduced in the Legislative Assembly. However, it was much later on the 19th of January, 1956, that life insurance in India was nationalized. About 154 Indian insurance companies, 16 non-Indian companies and 75 provident were operating in India at the time of nationalization. Nationalization was accomplished in two stages; initially the management of the companies was taken over by means of an Ordinance, and later, the ownership too by means of a comprehensive bill. The Parliament of India passed the Life Insurance Corporation Act on the 19th of June 1956, and the Life Insurance Corporation of India was created on 1st September, 1956, with the objective of spreading life insurance much more widely and in particular to the rural areas with a view to reach all insurable persons in the country, providing them adequate financial cover at a reasonable cost.

LIC had 5 zonal offices, 33 divisional offices and 212 branch offices, apart from its corporate office in the year 1956. Since life insurance contracts are long term contracts and during the currency of the policy it requires a variety of services need was felt in the later years to expand the operations and place a branch office at each district headquarter. Re-organization of LIC took place and large numbers of new branch offices were opened. As a result of re-organisation servicing functions were transferred to the branches, and branches were made accounting units. It worked wonders with the performance of the corporation. It may be seen that from about 200.00 crores of New Business in 1957 the corporation crossed 1000.00 crores only in the year 1969-70, and it took another 10 years for LIC to cross 2000.00 crore mark of new business. But with re-organisation happening in the early eighties, by 1985-86 LIC had already crossed 7000.00 crore Sum Assured on new policies.

Today LIC functions with 2048 fully computerized branch offices, 109 divisional offices, 8 zonal offices, 992 satallite offices and the Corporate office. LIC's Wide Area Network covers 109 divisional offices and connects all the branches through a Metro Area Network. LIC has tied up with some Banks and Service providers to offer on-line premium collection facility in selected cities. LIC's ECS and ATM premium payment facility is an addition to customer convenience. Apart from on-line Kiosks and IVRS, Info Centres have been commissioned at Mumbai, Ahmedabad, Bangalore, Chennai, Hyderabad, Kolkata, New Delhi, Pune and many other cities. With a vision of providing easy access to its policyholders, LIC has launched its SATELLITE SAMPARK offices. The satellite offices are smaller, leaner and closer to 
the customer. The digitalized records of the satellite offices will facilitate anywhere servicing and many other conveniences in the future.

LIC continues to be the dominant life insurer even in the liberalized scenario of Indian insurance and is moving fast on a new growth trajectory surpassing its own past records. LIC has issued over one crore policies during the current year. It has crossed the milestone of issuing 1,01,32,955 new policies by $15^{\text {th }}$ Oct, 2005, posting a healthy growth rate of $16.67 \%$ over the corresponding period of the previous year.

From then to now, LIC has crossed many milestones and has set unprecedented performance records in various aspects of life insurance business. The same motives which inspired our forefathers to bring insurance into existence in this country inspire us at LIC to take this message of protection to light the lamps of security in as many homes as possible and to help the people in providing security to their families.

\section{Some of the important milestones in the life insurance business in India are:}

$\square$ 1818: Oriental Life Insurance Company, the first life insurance company on Indian soil started functioning.

1870: Bombay Mutual Life Assurance Society, the first Indian life insurance company started its business.

1912: The Indian Life Assurance Companies Act enacted as the first statute to regulate the life insurance business.

1928: The Indian Insurance Companies Act enacted to enable the government to collect statistical information about both life and non-life insurance businesses.

$\square$ 1938: Earlier legislation consolidated and amended to by the Insurance Act with the objective of protecting the interests of the insuring public.

$\square$ 1956: 245 Indian and foreign insurers and provident societies are taken over by the central government and nationalised. LIC formed by an Act of Parliament, viz. LIC Act, 1956, with a capital contribution of ₹ 5 crore from the Government of India.

The General insurance business in India, on the other hand, can trace its roots to the Triton Insurance Company Ltd., the first general insurance company established in the year 1850 in Calcutta by the British.

The insurance sector has gone through a number of phases by allowing private companies to solicit insurance and also allowing foreign direct investment. India allowed private companies in insurance sector in 2000, setting a limit on FDI to 26\%, which was increased to $49 \%$ in 2014 . However, the largest life-insurance company in India, Life Insurance Corporation of India is still owned by the government and carries a sovereign guarantee for all insurance policies issued by it.

\section{Some Areas of Future Growth}

Life Insurance: The traditional life insurance business for the LIC has been a little more than a savings policy. Term life (where the insurance company pays a predetermined amount if the policyholder dies within a given time but it pays nothing if the policyholder does not die) has accounted for less than $2 \%$ of the insurance premium of the LIC (Mitra and Nayak, 2001). For the new life insurance companies, term life policies would be the main line of business. 
Health Insurance: Health insurance expenditure in India is roughly $6 \%$ of GDP, much higher than most other countries with the same level of economic development. Of that, $4.7 \%$ is private and the rest is public. What is even more striking is that $4.5 \%$ are out of pocket expenditure (Berman, 1996). There has been an almost total failure of the public health care system in India. This creates an opportunity for the new insurance companies. Thus, private insurance companies will be able to sell health insurance to a vast number of families who would like to have health care cover but do not have it.

Pension: The pension system in India is in its infancy. There are generally three forms of plans: provident funds, gratuities and pension funds. Most of the pension schemes are confined to government employees (and some large companies). The vast majority of workers are in the informal sector. As a result, most workers do not have any retirement benefits to fall back on after retirement. Total assets of all the pension plans in India amount to less than USD 40 billion.

Therefore, there is a huge scope for the development of pension funds in India. The finance minister of India has repeatedly asserted that a Latin American style reform of the privatized pension system in India would be welcome (Roy, 1997). Given all the pros and cons, it is not clear whether such a wholesale privatization would really benefit India or not (Sinha, 2000).

Other Non-Life Insurance: The flurry of activities of the new companies in the life insurance market has not been repeated in other types of insurance. The reason is basic: lack of data. Unless the new companies have access to reliable data on accidents of different kinds under Indian conditions, it would be hard to offer a competitive menu of policies.

It seems unlikely that the LIC and the GIC will shrivel up and die within the next decade or two. The IRDA has taken a "slowly slowly" approach. It has been very cautious in granting licenses. It has set up fairly strict standards for all aspects of the insurance business (with the probable exception of the disclosure requirements). The regulators always walk a fine line. Too many regulations kill the incentive for the newcomers; too relaxed regulations may induce failure and fraud that led to nationalization in the first place. India is not unique among the developing countries where the insurance business has been opened up to foreign competitors. From Table 4, we observe that the openness of the market did not mean a takeover by foreign companies even in a decade. Thus, it is unlikely that the same will happen in India, especially when the foreign insurers cannot have a majority shareholding in any company.

Table 1: Results of Openness and Foreign Penetration of Insurance in Asia

\begin{tabular}{cccccc}
\hline Country & \multicolumn{5}{c}{ Years } \\
\cline { 2 - 6 } & Years & Market & Open & Foreign & Penetration \\
\hline China & $0-5$ & $6-10$ & $11+$ & $0-10 \%$ & $11-20 \%$ \\
Malaysia & $\mathrm{X}$ (partial) & & & $\mathrm{X}$ & \\
Taiwan & & $\mathrm{X}$ & $\mathrm{X}$ & \\
Korea & & $\mathrm{X}$ & $\mathrm{X}$ & $\mathrm{X}$ & $\mathrm{X}$ \\
Indonesia & & & & $\mathrm{X}$ & \\
Japan & $\mathrm{X}$ & & & & \\
\hline
\end{tabular}

Sources: Speech by Lawrence P. Moews, CEO, Allstate International, International Insurance Society Conference, Sydney, Australia, 1997. 
The insurance business is at a critical stage in India. Over the next couple of decades we are likely to witness high growth in the insurance sector for two reasons. Financial deregulation always speeds up the development of the insurance sector. Growth in per capita GDP also helps the insurance business to grow.

\section{OBJECTIVES OF THE STUDY}

In view of the above discussions, we have two broad objectives of the present study:

1. To have an overview of the evolution and Growth of the Indian insurance industry.

2. To measure the growth and compare the same between the oldest Life Insurance Company LICI and the Private Insurance Business Sector in India.

\section{METHODOLOGY OF THE STUDY}

Keeping in mind the objectives of the study, we have tried to measure the growth of Insurance Sector in India through some specific financial as well as statistical techniques. Here we have used the concept of Compounded Annual Growth Rate (CAGR) to estimate the growth factor, which is the most effective parameter to measure the growth rate of any industry/investment by the financial analysts. The concept is explained below:

CAGR is the year-over-year growth rate of an investment over a specified period of time. The compound annual growth rate is calculated by taking the nth root of the total percentage growth rate, where $n$ is the number of years in the period being considered.

This can be written as follows:

$$
\text { CAGR }=\left(\frac{\text { Ending Value }}{\text { Beginning Value }}\right)^{\left(\frac{1}{\# \text { of years }}\right)}-1
$$

\# means 'number'

\section{Nature of Data}

I have taken top 8 financial years' data for the above-mentioned sector for a study period of Fy 2005-06 to 2012-13, based on three mostly used financial parameters of growth of a company like Total premium, regular premium, renewal premium, one-time premium and monthly/quarterly premium underwritten by the insurers. From individual data for each of the 5 sectors, we have computed CAGR of those 5 sectors over the study period and from there we have computed the Weighted Average CAGR of the insurance sector with the help of the following formula :

$$
£=\beta_{1} x_{1}+\beta_{2} x_{2}+\beta_{3} x_{3} \beta_{4} x_{4}
$$

Where,

$£=$ Weighted Average of the CAGRs

$\mathrm{B}_{\mathrm{i}}(\mathrm{i}=1,2,3,4)=\mathrm{CAGR}$ of the Individual sub-sector (out of the 5 sub-sectors)

$\mathrm{X}_{\mathrm{i}}(\mathrm{i}=1,2,3,4,5)=$ Respective Weights taking 2005-06 as Base Year. 
This weighted average CAGR for the LICI is denoted by $\mathrm{L}_{\mathrm{CAGR}}$. Similarly, we have computed the CAGR of Private Insurance sector. Over the same study period following the same process and denoted by $\mathrm{P}_{\mathrm{CAGR}}$ and the results are interpreted through some graphical as well as statistical tools like correlation coefficients, curve fitting etc.

\section{Period of Study}

Here, we have taken related data (financial and Statistical) from the Capitaline database, provided by Capital Markets Pvt. Ltd. and the Annual Reports of IRDA over the study period from Fy 2005-06 to 2012-13, in order to maintain the uniformity of the study.

\section{Tools for Analysis}

In order to analyse the collected data, we have used the financial tool 'CAGR'. Further, to understand whether the average growth rate of LICI had any impact on the same factor of the Private Sector or not, we have used the concept of Pearsonian correlation coefficients (i.e., $r$ ). Further, to test whether there was a significant difference between these two growth rates or not, we have made F-test and ANNOVA with the following hypotheses :

$\mathrm{H}_{0}=$ There is no significant difference between the $\mathrm{L}_{\mathrm{CAGR}}$ and $\mathrm{P}_{\mathrm{CAGR}}$.

$\square \mathrm{H}_{1}=$ There is Significant difference between the two.

Further, to diagnose the reasons behind the huge variation of CAGR of the LICI and that of the Private Insurance Sector, we have tried to estimate a non-linear relationship by curve fitting method and here we have fitted 9 non-linear curves (using PASW software) in order to predict the best relationship between this two in future also.

\section{SECONDARY DATA ANALYSIS ON THE BASIS OF SPECIFIC METHODOLOGY}

\section{Trend of CAGR of LICI and that of the Private Insurance Sector}

Table 2 : Trend of CAGR of LICI and that of the Private Insurance Sector

\begin{tabular}{ccccccccc}
\hline & $\mathbf{2 0 1 0 - 1 1}$ & $\mathbf{2 0 1 1 - 1 2}$ & $\mathbf{2 0 1 2 - 1 3}$ & $\mathbf{2 0 1 3 - 1 4}$ & $\mathbf{2 0 1 4 - 1 5}$ & $\mathbf{2 0 1 5 - 1 6}$ & $\mathbf{2 0 1 6 - 1 7}$ & AVG. \\
\hline LIC CAGR & 40.79 & 28.44 & 20.1 & 19.65 & 17.51 & 14.34 & 12.63 & 21.92286 \\
PRIVATE SECTOR CAGR & 87.08 & 84.89 & 62.32 & 43.8 & 39.39 & 34.21 & 27.84 & 54.21857 \\
\hline
\end{tabular}

Sources: Computed from various IRDA Annual Reports.

The table 2 clearly depicts that in the industry CAGR, there is a smooth downward shift which is remarkable both in case of LICI and that of the Private Insurance Sector, the average growth rate of LICI stood at $21.93 \%$ which is more than doubled by the private insurance sector which stood at $54.22 \%$ during the period under study. 
Again, to understand the relationship between the LICI growth rate and that of the private insurance sector over the study period, we have used the concept of straight line trend, which have been shown graphically over the entire study period. This linear shift over the study period has been depicted through a comparative line chart which is presented underneath:

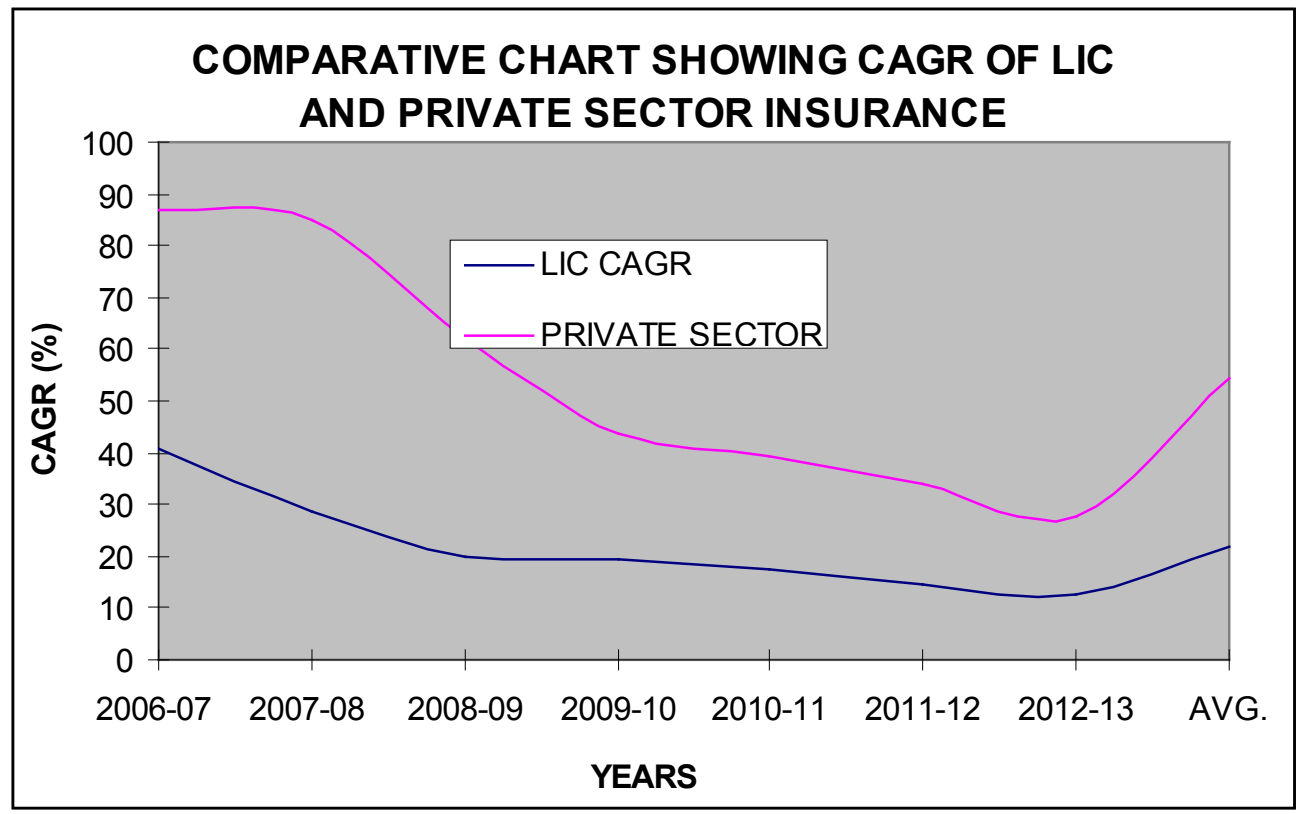

This chart shows that the LICI CAGR was beating the private insurance sector over the study period.

\section{Use of Correlation Coefficient (r)}

Further, to understand whether average growth rate of LICI had any impact on the growth of the private insurance sector, we have used the concept of Pearsonian correlation coefficient (i.e., r). The results are depicted through Table 3 and Table 4 as presented below :

Table 3: Descriptive Statistics

\begin{tabular}{cccc}
\hline & Mean & Std. Deviation & N \\
\hline CAGRL & 21.9229 & 9.74903 & 7 \\
CAGRP & 54.2186 & 24.18970 & 7 \\
\hline
\end{tabular}

Table 4: Correlations

\begin{tabular}{cccc}
\hline & CAGRL & CAGRP \\
\hline CAGRL & Pearson Correlation & 1 & $.912(* *)$ \\
Sig. (2-tailed) & - & .004 \\
& Sum of Squares and Cross-products & 570.261 & 1291.094 \\
& Covariance & 95.044 & 215.182
\end{tabular}


CAGRP

\author{
Pearson Correlation \\ Sig. (2-tailed) \\ Sum of Squares and Cross-products \\ Covariance
}

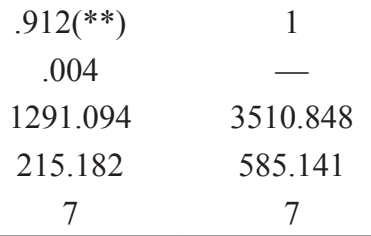

** Correlation is significant at the 0.01 level (2-tailed).

Table 3 clearly shows that CAGR of Private sector has a greater variation than the CAGR of the LICI as a whole. It depicts that the LICI average growth is more or less stable. Table 4 clearly indicates that Person Correlation coefficient (r) between LICI CAGR and Private sector CAGR is positive and very high as well as significant, i.e., the LICI growth rate directly affects the Private Sector growth rate.

Further, to test whether there was a significant difference between these two growth rates or not, we have made t-test and F-test and ANNOVA with the following hypotheses:

$\square \mathrm{H}_{0}=$ There is no significant difference between the LICI CAGR of the industry and that of the Private Sector.

$\square \mathrm{H}_{1}=$ There is Significant difference between the two.

The results are depicted through the following table :

Table 5: One-Sample t-Test

\begin{tabular}{lcccccc}
\hline & \multicolumn{8}{c}{ Test Value = } \\
\cline { 2 - 7 } & $\mathbf{t}$ & df & Sig. (2-tailed) & $\begin{array}{c}\text { Mean } \\
\text { Difference }\end{array}$ & $\begin{array}{c}\text { 95\% Confidence Interval of the } \\
\text { Difference }\end{array}$ \\
\hline & Lower & Upper & Lower & Upper & Lower & Upper \\
\cline { 2 - 7 } LCAGR & 12.073 & 8 & .000 & 17.00222 & 13.7547 & 20.2497 \\
PCAGR & 18.986 & 8 & .000 & 27.60000 & 24.2477 & 30.9523 \\
\hline
\end{tabular}

The table 5 clearly shows that he significance factor is 0.000 which indicates that null hypothesis is rejected, i.e., there is a significant difference between the two averages.

Again, to diagnose the reasons behind the huge variation of CAGR of the LICI and that of the Private Insurance sector, we have tried to estimate a non-linear relationship by curve fitting method and here we have fitted 9 non-linear curves (using PASW software) in order to predict the best relationship between this two in future also. The result is depicted through the following table 6 :

Table 6: Model Summary and Parameter Estimates

Dependent Variable: LICI CAGR

\begin{tabular}{|c|c|c|c|c|c|c|c|c|c|}
\hline \multirow[t]{2}{*}{ Equation } & \multicolumn{5}{|c|}{ Model Summary } & \multicolumn{4}{|c|}{ Parameter Estimates } \\
\hline & R Square & $\mathbf{F}$ & df1 & df 2 & Sig. & Constant & b1 & b2 & b3 \\
\hline Linear & .158 & 1.314 & 1 & 7 & .289 & 20.623 & .410 & & \\
\hline Logarithmic & .236 & 2.167 & 1 & 7 & .184 & 4.658 & 8.180 & & \\
\hline Inverse & .313 & 3.190 & 1 & 7 & .117 & 36.484 & -142.297 & & \\
\hline
\end{tabular}




$\begin{array}{cccccccccc}\text { Quadratic } & .547 & 3.627 & 2 & 6 & .093 & -15.447 & 4.805 & -.127 & -002 \\ \text { Cubic } & .562 & 3.842 & 2 & 6 & .084 & -5.056 & 2.761 & .000 & -.002 \\ \text { Compound } & .167 & 1.402 & 1 & 7 & .275 & 20.728 & 1.016 & & .326 \\ \text { Power } & .256 & 2.411 & 1 & 7 & .164 & 10.933 & .063 & -5.733 & \\ \text { S } & .347 & 3.715 & 1 & 7 & .095 & 3.664 & .016 & \\ \text { Growth } & .167 & 1.402 & 1 & 7 & .275 & 3.031 & .016 & \\ \text { Exponential } & .167 & 1.402 & 1 & 7 & .275 & 20.728 & .984 & \\ \text { Logistic } & .167 & 1.402 & 1 & 7 & .275 & .048 & \end{array}$

The independent variable is PCAGR.

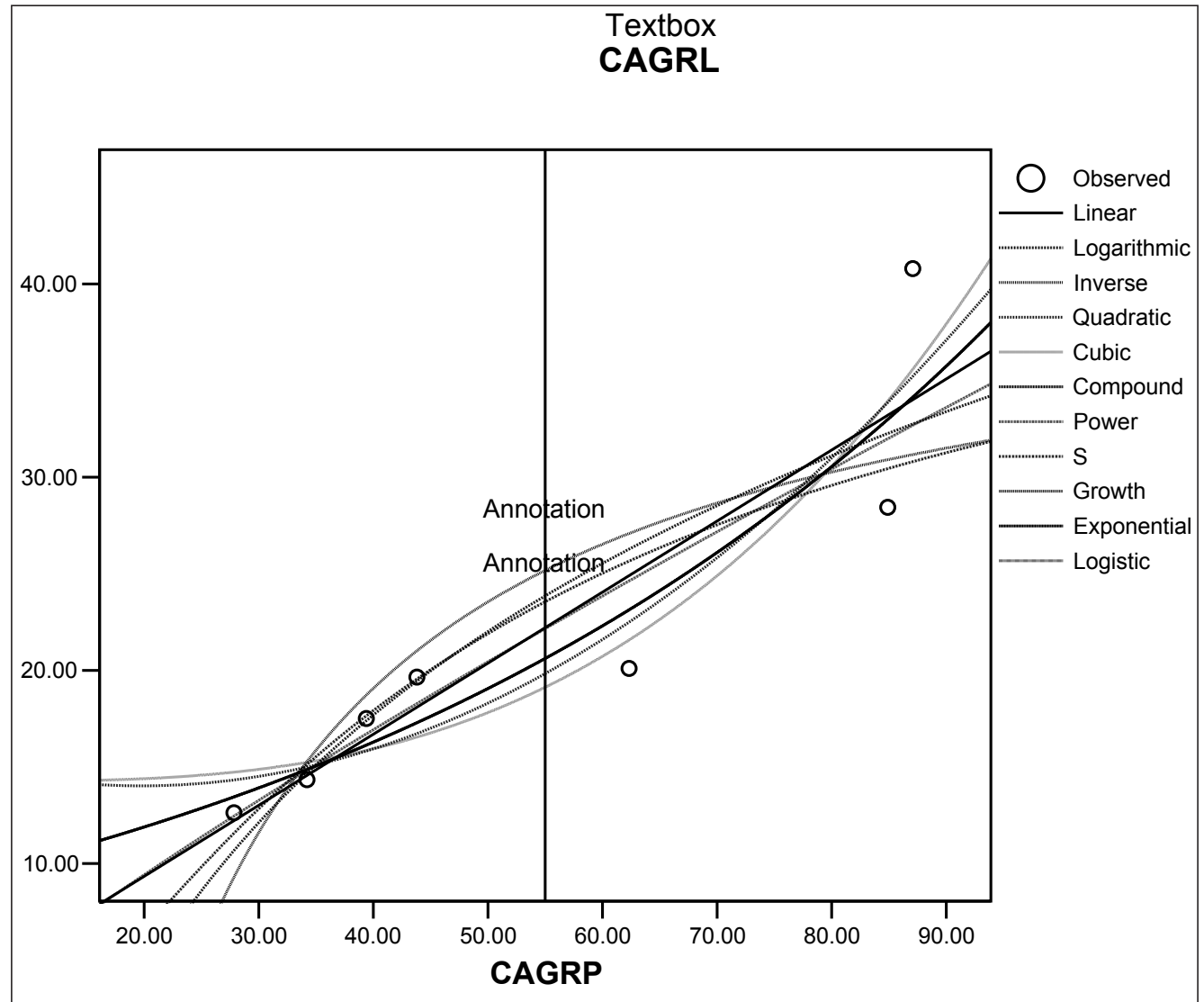

From the above exhibit, we see that the best fitted curve is the Inverse curve model, which gives us the following equation to explain the values of CAGRL is how much related to CAGRP :

$$
\mathrm{Y}=0.4103855398624111 * \mathrm{X}+20.62253385447265
$$

Where, $\mathrm{Y}=\mathrm{CAGRL}$

$$
\mathrm{X}=\text { mean CAGRP. }
$$


This helps us to predict a model which will predict the value of CAGRL depending on CAGRP of the insurance sector.

\section{FINDINGS OF THE STUDY}

On the basis of the above analysis, we present the following findings :

1. The premiums underwritten by the life insurers in terms of regular premium, single premium, first year premium, renewal premium and total premium are increasing for both LIC and private insurance sector over the study period, although the same is having almost $2 / 3$ fold increase in case of LIC. The correlation coefficient between LIC and Private Sector is $0.26,0.74,0.80,0.97$ and 0.97 respectively in case of regular premium, single premium, first year premium, renewal premium and total premium, which indicates that there is a close association between these two sectors so far as premium underwritten by the insurers is concerned.

2. The market share of life insurers in respect of LIC varied from $68.08 \%$ to $83.92 \%$ whereas that of private insurance sector varied from $16.08 \%$ to $41.92 \%$ during the said study period of 2005-06 to 2012-13 and another important factor to see is that the market share of LIC has an increasing trend and that of private insurance sector is having a decreasing trend during the study period. It may depict higher reliance of the life insurers on LIC rather than the private insurance sectors during the said study period.

3. The growth of LICI in terms of new policies issued is much faster than that of the Private Insurance Sector over the study period, although during the first two years, the growth of private sector was much rapid than LICI. But, as a whole, LICI maintained a consistent growth over the years.

4. LIC had a stable and private insurance sector had very fluctuating trend so far as new policies issued by the life insurers during the study period. New policies ranging from $₹ 315.9$ crores to ₹ 388.63 crores during the study period in case of LIC, although that ranging from $₹ 84.42$ crores ₹ 792.22 crores during the said study period. Very much interesting to see the although in terms of issuing new policies, the total value started flourishing during the beginning of the study period, but at the end of the study period, i.e., during 2012-13, the same badly diminished. It may be due to the fact that there is a fear factor and misconception of the general life insurers about the private sector, which enhanced further due to the market crash of AIG, a giant firm, in the private life insurance sector in USA in 2008.

5. The capital investment by the private insurance sector is much higher than the LICI over the study period although the later enjoys a much higher growth in terms of new policies and total number of premiums.

6. The enhanced commission of the life insurers in LICI than that of the private insurance sector, which mainly induces the life insurers towards LICI.

7. The operating expenses of private insurance sector is much higher than LICI, may be because of the fact that to keep pace with the steep competition, they have to maintain a high-salaried staff potential.

8. The reflection of the previous table which emphasises on the fact that there is a sharp increase of the operating ratio in the private insurance sector than in the LICI. 
9. The business increases over the passage of time, there is an increase in the number of offices held by the Private Insurance sector which is much higher in comparison with that of the LICI.

10. In the industry CAGR, there is a smooth downward shift which is remarkable both in case of LICI and that of the Private Insurance Sector, the average growth rate of LICI stood at $21.93 \%$ which is more than doubled by the private insurance sector which stood at $54.22 \%$ during the period under study.

11. Again, to understand the relationship between the LICI growth rate and that of the private insurance sector over the study period, we have used the concept of straight line trend, which have been shown graphically over the entire study period. This chart shows that the LICI CAGR was beating the private insurance sector over the study period.

12. Further, to understand whether average growth rate of LICI had any impact on the growth of the private insurance sector, we have used the concept of Pearsonian correlation coefficient (i.e., r). it shows that CAGR of Private sector has a greater variation than the CAGR of the LICI as a whole. It depicts that the LICI average growth is more or less stable. Table 11 clearly indicates that Person Correlation coefficient (r) between LICI CAGR and Private sector CAGR is positive and very high as well as significant, i.e., the LICI growth rate directly affects the Private Sector growth rate.

13. Further, to test whether there was a significant difference between these two growth rates or not, we have made t-test and F-test and ANNOVA with the following hypotheses :

$\square \mathrm{H}_{0}=$ There is no significant difference between the LICI CAGR of the industry and that of the Private Sector.

$\square \mathrm{H}_{1}=$ There is Significant difference between the two.

The significance factor is 0.000 which indicates that null hypothesis is rejected, i.e., there is a significant difference between the two averages.

14. Again, to diagnose the reasons behind the huge variation of CAGR of the LICI and that of the Private Insurance sector, we have tried to estimate a non-linear relationship by curve fitting method and here we have fitted 9 non-linear curves (using PASW software) in order to predict the best relationship between this two in future also. The best fitted curve is the Inverse curve model, which gives us the following equation to explain the values of CAGRL is how much related to CAGRP : $\mathrm{Y}=0.4103855398624111 * \mathrm{X}+20.62253385447265$

Where, $\mathrm{Y}=\mathrm{CAGRL}$

$$
\mathrm{X}=\text { mean CAGRP. }
$$

This helps us to predict a model which will predict the value of CAGRL depending on CAGRP of the insurance sector.

\section{CONCLUSION}

The growth of insurance sector in India at present is nearly $27.00 \%$ per year. The rise in the growth rate suggests the growth of the economy. The financial policies and the monetary policies are able to sustain 
a stable growth rate. The reforms pertaining to the monetary policies and the macro economic policies over the last few years have influenced the Indian economy to the core. The major step towards opening up of the financial market further was the nullification of the regulations restricting the growth of the financial sector in India. To maintain such a growth for a long term the inflation has to come down further. The insurance sector in India had an overall growth of $27 \%$, which has exhibited stability over the last few years although several other markets across the Asian region were going through turmoil. The development of the system pertaining to the financial sector was the key to the growth of the same. With the opening of the financial market variety of products and services were introduced to suit the need of the customer. The Insurance Regulatory Authority of India (IRDA) played a dynamic role in the growth of the insurance sector of India.

\section{REFERENCES}

1. Athukorala, Prema-Chandra and Kunal Sen, 2002. Saving, Investment, and Growth in India (New Delhi: Oxford University Press).

2. Balakrishnan, Pulapre 2006. Benign Neglect or Strategic Intent? Contested Lineage of Indian Software Industry, Economic and Political Weekly, September 9, pp. 3865-3872.

3. Banerjee, Abhijit V. and Esther Duflo, 2000. "Reputation Effects and the Limits of Contracting: A Study of the Indian Software Industry," Quarterly Journal of Economics,115(3): 989-1017.

4. Basu, I. 2003. India's Growing Urge to Splurge, Asia Times Online, http:/www.atimes.com/atimes/ South_Asia/EH22Df01.html, accessed January 4, 2005.

5. Baumol, W. J. 1967. "Macroeconomics of Unbalanced Growth: The Anatomy of Urban Crises." American Economic Review, 57(3): 415-26.

6. Bell, Clive and Peter L. Rousseau, 2001. "Post - Independence India: A Case of Finance - Led Industrialization?” Journal of Development Economics, 65(1): 153-75.

7. Chand, Satish and Kunal Sen 2002. Trade Liberalization and Productivity Growth: Evidence from Indian Manufacturing, Review of Development Economics, 6(1): 120-32.

8. Ciaschini, M. 1988. (ed.), Input-Output Analysis, London: Chapman and Hall Ltd.

9. Ciccone, Antonio and Kiminori Matsuyama 1996. Start-up Costs and Pecuniary Externalities as Barriers to Economic Development, Journal of Development Economics, 49(1): 33-59.

10. Claus, Iris 2002. 'Inter Industry Linkages in New Zealand', Working Paper 02/09, June, New Zealand Treasury.

11. Coase, Ronald 1937. The Nature of the Firm, Economica, 4: 386-405. 
12. Dahlman, Carl 2006. Technology, Globalization, and International Competitiveness: Challenges for Developing Countries, UNDESA project paper draft.

13. Ethiraj, Sendil K., Prashant Kale, M.S. Krishnan and Jitendra V. Singh, 2005. Where Do Capabilities Come From and How Do They Matter? A Study in the Software Services Industry, Strategic Management Journal, 26: 25-45.

14. Gordon, James, and Poonam Gupta 2004. 'Understanding India’s Services Revolution', IMF Working Paper WP/04/171, September.

15. Griliches, Zvi 1992. (ed.), Output Measurement in the Service Sectors, NBER Studies in Income and Wealth, Vol. 56, University of Chicago Press, Chicago.

16. Grossman, Gene M. and Elhanan Helpman 1991. Innovation and Growth in the Global Economy, Cambridge, MA: MIT Press.

17. Gulyani, Sumila 2001. 'Effects of poor transportation on lean production and industrial clustering: Evidence from the Indian auto industry,' World Development, 29(7): 1157-1177.

18. Hansda, Sanjay K. 2001. 'Sustainability of Services-led Growth: An Input-Output Analysis of Indian Economy, RBI Occasional Working Paper, 22(1,2 and 3).

19. Hansda, Sanjay K. 2002. Services Sector in the Indian Growth Process: Myths \& Realities, The Journal of Income and Wealth.

20. Kelkar, Vijay 2004. India: On the Growth Turnpike, K.R. Narayanan Oration, Australian National University.

21. Khan Sabith Ullah 2003. Backward \& Forward Linkages in the ITES/ BPO Industry, Centre for Civil Society, New Delhi.

22. Kochhar, Kalpana, Utsav Kumar, Raghuram Rajan, Arvind Subramanian, Ioannis Tokatlidis 2006. India's Pattern of Development: What Happened, What Follows?, IMF Working Paper WP/06/22.

23. Kravis, Irving B., Alan Heston, and Robert Summers 1983. 'The Share of Service in Economic Growth', in Global Econometrics: Essays in Honor of Lawrence R. Klein, (ed.) F. Gerard Adams and Bert G. Hickman, Cambridge MA, pp. 188-219.

24. Kuznets, S. 1959. Six Lectures on Economic Growth, The Free Press of Glencoe, New York. Lovelock, Christopher, and Evert Gummesson (2004), Whither Services Marketing? In Search of a New Paradigm and Fresh Perspective, Journal of Service Research, 7(1): 20-41.

25. Majumdar, Mukul and Ilaria Ossella 1999. Identifying Leading Sectors that Accelerate the Optimal Growth Rate: A Computational Approach, in Trade, Growth and Development: Essays in Honor of Professor T.N. Srinivasan, Amsterdam: Elsevier Science, pp. 273-290.

26. Melvin, James R. 1989. Trade in Services: A Theoretical Analysis, Institute for Research on Public Policy, Halifax. 
27. Melvin, James R. 1990. Time and Space in Economic Analysis, Canadian Journal of Economics, 23: $725-747$.

28. Pack, Howard and Larry Westphal 1986. Industrial Strategy and Technological Change: Theory versus Reality, Journal of Development Economics, 22: 87-128.

29. Panagariya, Arvind 2005. The Triumph of India's Market Reforms: The Record of the 1980s and 1990s, Policy Analysis, November 7, No. 554.

30. Panagariya, Arvind 2006. Transforming India, paper presented at the conference "India: An Emerging Giant," October 13-15, 2006, Columbia University.

31. Pandit, V. N. 2002. "Sustainable Economic Growth for India: An Exercise in Macroeconomic Scenario Building," CDEDSE Working Paper 100.

32. Parasuraman, A., Valarie A. Zeithaml, and Leonard L. Berry 1985. 'A Conceptual Model of Service Quality and Its Implications for Future Research,' Journal of Marketing, 49(Fall): 41-50.

33. Planning Commission 2001. Report of the Task Force on Employment Opportunities, chaired by Montek S. Ahluwalia, New Delhi, Government of India.

34. Planning Commission 2002. Report of the Special Group on Targeting Ten Million

35. Employment Opportunities per year over the Tenth Plan Period, chaired by S.P. Gupta, New Delhi, Government of India.

36. Rajan, Raghuram, and Luigi Zingales 2006. The Persistence of Under development:

37. Institutions, Human Capital, or Constituencies? Working Paper 12093, National Bureau of Economic Research.

38. Rao, M. Govinda 2005. Should Indians pay more in taxes?, Business Standard, February 12 , available at http://www.business-standard.com/search/storypage_new.php?leftnm $=1$ mnu5 \& leftindx $=5 \& 1$ select $=1 \&$ autono $=180612$, accessed April 27, 2005

39. Rasmussen, P.N. 1956. Studies in Intersectoral Relations, Amsterdam: North Holland.

40. Reserve Bank of India 2006. Handbook of Statistics for the Indian Economy, www.rbi.org.in.

41. Sapir, A. and C. Winter 1994. 'Services Trade', in D. Greenaway and L. Winters (eds.), Surveys in International Trade, Blackwell Economic Theory and the Role of Government in East Asian Industrialization, Princeton University Press, Princeton.

42. Singh, Nirvikar 2004b. Information Technology and Rural Development in India, in Integrating the Rural Poor into Markets, Bibek Debroy and Amir Ullah Khan, eds., New Delhi: Academic Foundation, pp. 221-246.

43. Singh, Nirvikar 2004c. Information Technology and India's Economic Development, in India's Emerging Economy: Performance and Prospects in the 1990's and Beyond, ed. K. Basu, MIT Press, pp. 223-261

44. Singh, Nirvikar 2005. ICTs and Rural Development in India, University of California, Santa Cruz, USA, Draft, in progress, December. 
45. Singh, Nirvikar and T.N. Srinivasan 2005. Indian Federalism, Economic Reform and Globalization, in Jessica Wallack and T.N. Srinivasan, eds., Federalism and Economic Reform: International Perspectives: Cambridge University Press, pp. 301-363.

46. Singh, Nirvikar and T.N. Srinivasan 2006. Federalism and Economic Development in India: An Assessment, October, UCSC Economics Department Working Paper No. 625.

47. Srinivasan, T.N. 2003. Indian Economy: Current Problems and Future Prospects, Working Paper No. 173, Stanford Center for International Development, July.

48. Srinivasan, T.N. 2005. Information Technology Enabled Services and India's Growth Prospects, Forthcoming in Lael Brainard and Susan M. Collins (editors): Offshoring White-Collar Work-The Issues and Implications, The Brookings Trade Forum.

49. Sundaram, K. 2004. Growth of Work Opportunities In India: 1983 - 1999-2000, Centre for Development Economics, Delhi School of Economics, India

50. Triplett Jack E. and Barry P. Bosworth, 2004. Productivity in the U.S. Services Sector: New Sources of Economic Growth, Brookings Institution Press.

51. Vargo, Stephen L. and Robert F. Lusch 2004. Evolving to a New Dominant Logic for Marketing, Journal of Marketing, 68: 1-17. 
